\title{
RELIGIOSITY AMONG CRIMINALS WITH DEATH PINALTY: A STUDY OF NUSAKAMBANGAN PRISON
}

\author{
NOVIA FETRI ALIZA*, PUTRIKRISDIANA**, Y USRI HAMZAN I** \\ *Fakultas Agama Islam, Universitas Muhammadiyah Yogyakarta Jl. Brawijaya, Tamantirto, Daerah Istimewa Yogyakarta, \\ Email: novia.psikolog@gmail.com. **Alumni Fakultas Agama Islam, Universitas Muhammadiyah Yogyakarta, JI. Brawijaya, \\ Tamantirto, Daerah Istimewa Yogyakarta, Email: putrikrisdiana19@gmail.com. *** Sekolah Tinggi Agama Islam Darul Kamal \\ Nahdlatul Wathan, JI. Segara Anak Kembang Kerang Daye, Lombok Timur, NTB, Email: yusri231192@gmail.com
}

\begin{abstract}
This article discusses religiosity among criminals who pleaded guilty with death penalty at Lembaga Pemasyarakatan (Lapas) Permisan Nusakambangan. This focuses on two major issues; religiosity among the criminals and factors that contribute to the level of religiosity. The author carries out a field research by conducting interview and documentation. Subjects of the research are limited to three main categories; Muslim males in Indonesia, punished with capital punishment, and waiting for execution for more than ten years. The data obtained are analyzed using a theory of religiosity that is developed in religious study and psychology. The result of the study shows that the religiosity of the criminals who are punished with capital punishment are very good based on aspects of religiosity, such as; belief, Islamic law, and behavior of the criminals. Moreover, this religiosity is affected by internal and external factors. Internal factors relate to their confession of the past sins and the fear of death, while the external factors relate to the roles of their parents, children, and wife.
\end{abstract}

KATA KUNCI: religiosity, criminals, capital punishment, psychology

\section{RELIGIUSITAS NARAPIDANA VONIS HUKUMAN MATI: STUDI LEMBAGA PEMASYARAKATAN NUSAKAMBANGAN}

\begin{abstract}
Abstrak
Artikel ini membahas tentang religiusitas narapidana vonis hukuman mati di Lembaga Pemasyarakatan Permisan Nusakambangan. Terdapat dua pembahasan utama yang dikaji dalam artikel ini: kondisi religiusitas narapidana vonis hukuman mati yang saat ini mendekam di lapas Permisan dan faktor-faktor yang membentuk sikap religius mereka. Untuk mendapatkan data seputar dua pembahasan utama tersebut, penulis menggunakan jenis penelitian lapangan dengan metode wawancara dan dokumentasi. Subjek dalam pembahasan ini juga dibatasi pada tiga kategori, yaitu orang Indonesia yang beragama Islam, mendapatkan vonis hukuman mati, sedang dalam masa menunggu eksekusi mati lebih dari sepuluh tahun dan berjenis kelamin laki-laki. Pada tahap selanjutnya, informasi yang didapatkan pada subjek penelitian tersebut dianalisis menggunakan teori religiusitas yang terdiri dari tiga dimensi utama, yaitu akidah, syariah, dan akhlak. Berdasarkan beberapa data yang didapatkan, kondisi religiusitas narapidana vonis hukuman mati di lapas Permisan sangat baik, hal ini terlihat dari pelaksanaan tiga dimensi utama religiusitas itu sendiri. Pada sisi kedua, religiusitas narapidana dipengaruhi oleh faktor internal berupa kesadaran atas dosa masa lalu dan ketakutan akan kematian. Sedangkan motivasi eksternal didapatkan dari orang tua, anak dan istri.
\end{abstract}

KATA KUNCI: religiusitas, narapidana, hukuman mati, psikologi

* Naskah diterima Agustus 2020, direvisi September 2020, dan disetujui untuk diterbitkan November 2020 


\section{A. Pendahuluan}

Bagi sebagian orang, kematian merupakan masa depan yang cukup mengerikan, bahkan menakutkan. Selain faktor keadaan atau kehidupan masa lalu, ketakutan akan kematian itu sendiri merupakan komponen penting dalam pembentukan formulasi psikologis seseorang. Tidak mengherankan jika rasa takut terhadap kematian, menjadi salah satu faktor yang mengakibatkan sebagian orang beramai-ramai mempersiapkan bekal dalam menghadapinya, baik melalui ritual pribadatan yang bercorak religi, ataupun dengan melakukan bakti sosial atau aksi kemanusiaan lainnya. Realitas tersebut dapat disaksikan pada narapidana vonis hukuman mati di Lembaga Pemasyarakatan (selanjutnya disingkat Lapas) Kelas IIA Permisan di Nusakambangan. Mereka "mengecas" religiusitas mereka dengan melaksanakan berbagai macam jenis kebaikan agar lebih siap menghadapi eksekusi hukuman mati.

Hukuman mati di Indonesia memang kerap kali menimbulkan sikap pro dan kontra. Sikap pro didasarkan atas bentuk pencegahan (langkah preventif) terjadinya kejahatan-kejahatan serupa yang tentunya akan merugikan warga sekitar dan supaya tercipta efek jera bagi pelakunya. Walaupun demikian, pihak pro juga memberikan masukan supaya hukuman mati harus melalui proses yang selektif dan bukan sebagai legalisasi atas aksi balas dendam. Sedangkan argumentasi dari pihak kontra dilandaskan atas asas humanisme; semua manusia berhak untuk hidup dan menjalani kehidupan dengan layak (Eddoyono, 2015). Terlepas dari silang pendapat tersebut, hukuman mati telah mendapatkan tempat pada tatanan hukum positif di Indonesia, bahkan tata cara pelaksanaannya telah diatur dalam Undang-Undang Nomor 2/PNS/1964 yang masih berlaku hingga saat ini.

Dalam realitasnya, hukuman mati tidak selalu dilaksanakan dengan segera dan secepat mungkin sebagaimana yang tertera dalam Pasal 197 ayat 3 Kitab Undang-Undang Hukum Acara Pidana. Hal ini tentu saja merugikan para terpidana hukuman mati, karena selain harus menunggu eksekusi, mereka juga harus mendekam di balik jeruji besi.

Secara psikologis, keadaan tersebut berimbas kepada gangguan-gangguan tertentu, seperti stres yang dialami oleh para terpidana mati. Selain itu, realitas tersebut juga menciptakan keadaan sosial yang kurang kondusif, bahkan penumpukan narapidana dalam sebuah Lapas, sebagaimana yang pernah terjadi di Lapas Permisan Nusakambangan pada tahun 2017. Beberapa dampak tersebut tentu saja di luar tujuan utama dari Lapas yang menginginkan warga binaannya menjadi manusia yang lebih baik, sebagaimana yang diatur dalam Bab 1 Pasal 1 UU No. 12 Tahun 1995.

Secara objektif, harus pula diakui bahwa program pembinaan yang diberikan oleh petugas Lapas tentu harus didukung pula dengan usaha dari narapidana itu sendiri. Setidaknya, dengan mencari cara agar dapat menjalani sisa hidupnya dengan lebih baik, sebelum hari eksekusinya tiba. Oleh karena itu, sangat penting bagi terpidana mati mencari alasan untuk tetap menjalani hidup dengan normal, serta menemukan tujuan hidupnya dan menata kembali formulasi hidup yang lebih bermakna.

Dengan demikian, mereka akan tetap menikmati sisa hidupnya dan bahkan kematian adalah hal yang bermakna, sebagaimana yang dinyatakan oleh Nietzche dan dikutip oleh Frankl, "... siapa yang memiliki suatu alasan (why) untuk hidup, maka akan sanggup mengatasi persoalan hidup dengan cara (how) apapun ..." (Frankl, 2003)

Sebagai narapidana yang memeluk agama Islam dan akan menghadapi eksekusi hukuman mati, tentunya tidak ada tujuan hidup yang lebih bermakna selain menyerahkan diri (tawakkal) kepada Tuhan yang disertai dengan proses penghayatan dan dikaitkan dengan rasa cinta kepadaNya, serta diekspresikan dengan penerapan nilai-nilai agama dalam kehidupan sehari-hari. Hal ini merupakan khazanah kecintaan seluruh umat beragama yang terlahir dari perenungan ruhani mereka (Tasmara, 2001).

Perilaku religius semacam itu, dapat menjadi salah satu solusi yang bersifat psikologis bagi seseorang yang sedang berada dalam tekanan, karena religiusitas sendiri merupakan salah satu faktor utama dalam kehidupan masyarakat beragama. Dari gambaran ini, dapat diketahui bahwa para narapidana hukuman mati memang mengalami "pasang-surut" kondisi psikologis yang turut serta mempengaruhi kondisi religiusitas mereka.

Kesiapan mereka dalam menghadapi eksekusi hukuman mati dapat dilihat dan dicermati dari perilaku keberagamaan mereka 
sehari-hari, baik yang bersifat ritual peribadatan ataupun ritual kesalehan sosial. Melihat bagaimana terpidana hukuman mati menjalani sisa-sisa kehidupan mereka dan dinamika kondisi psikologis yang mereka alami merupakan realitas yang menarik untuk ditelisik, ditelusuri, dan diteliti kembali, setidaknya dalam rangka memperkaya khazanah pengetahuan kita tentang kondisi religiusitas para narapidana hukuman mati yang saat ini masih menunggu hari eksekusi mati.

Harus diakui pula bahwa penelitian tentang tema ini telah mendapat banyak perhatian sebagaimana yang terlihat pada beberapa penelitian sebelumnya, seperti penelitian Leni Oktavia dengan judul Pelaksanaan Pembinaan Narapidana yang Dijatuhi Pidana Hukuman Mati (Studi Kasus Lembaga Pemasyarakatan Kelas IA Raja Basa Bandar Lampung) yang memberikan gambaran tentang bentuk pembinaan dan pendampingan secara jasmani dan rohani yang sangat bermanfaat bagi para narapidana agar tidak merasa stres dan dapat menjalankan sisa hidupnya dengan cara yang positif (Oktavia, 2019).

Selain penelitian Oktavia, ada pula penelitian Evi Nurul Hidayah dengan judul Proses Bimbingan Konseling Islami dalam Upaya Penyadaran Hidup Bermakna (Studi Kasus: Narapidana Vonis Hukuman Mati Lapas Kelas IIA Permisan Nusa Kambangan) yang menjelaskan tentang betapa pentingnya melakukan proses bimbingan konseling dalam rangka mempersiapkan mental narapidana yang akan menghadapi eksekusi mati (Hidayah, 2018).

Tema ini juga pernah diteliti oleh Dwi Arista dengan judul Kebermaknaan Hidup dan Religiusitas Pada Mantan Narapidana Kasus Pembunuhan (Di Kabupaten Paser) yang memaparkan panjang lebar tentang para narapidana yang telah merasakan kebermaknaan hidup dalam dirinya yang diwujudkan dalam bentuk kebahagiaan dan ketenangan dalam menjalani kehidupan dengan melibatkan sifat ikhlas dan syukur dalam diri mereka (Arista, 2017).

Perbedaan tulisan ini dengan beberapa penelitian di atas adalah perbedaan fokus penelitian. Tulisan Oktavia membahas tentang pelaksanaan pembinaan sebagai upaya meminimalisir kemungkinan terjadinya stres pada narapidana dalam proses masa menunggu eksekusinya, sedangkan penelitian ini membahas tentang penerapan religiusitas narapidana itu sendiri dalam menjalankan sisa kehidupannya sebelum tiba hari eksekusi mati.

Penelitian Evi Nurul Hidayah fokus membahas tentang proses bimbingan konseling Islami yang dilakukan oleh Lapas, sedangkan tulisan ini fokus untuk mendeskripsikan gambaran religiusitas para terpidana mati. Sedangkan perbedaan tulisan ini dengan penelitian Dwi Arista adalah subjek penelitian. Jika Arista menjadikan mantan narapidana sebagai subjeknya, maka tulisan ini memilih beberapa orang dengan status narapidana yang mendapatkan vonis hukuman mati namun masih mendekam di Lapas.

\section{B. Metode Penelitian}

Penelitian ini dilakukan di Lapas Kelas IIA Permisan Nusakambangan yang merupakan Lapas untuk para narapidana yang mendapat vonis hukuman mati di Indonesia. Jenis dari penelitian ini adalah kualitatif dengan menggunakan pendekatan deskriptif-analitis. Dimana peneliti mencoba untuk menggali data secara langsung dengan subjek penelitian, mengamati secara langsung agar dapat memperoleh data yang natural tentang bagaimana kondisi religiusitas para narapidana vonis hukuman mati.

Pada penelitian ini terdapat satu variabel yang dioperasionalkan dan menjadi fokus penelitian, yaitu variabel religiusitas narapidana. Beberapa indikator yang dibentuk dalam menjawab masalah yang diajukan adalah religiusitas yang dapat diukur dengan tiga dimensi keberagamaan, yaitu dimensi keyakinan atau aqidah Islam, dimensi peribadatan atau syariah, dan dimensi perilaku atau akhlak (Habanakah, 2004).

Adapun subjek dari penelitian ini adalah narapidana yang berada di Lapas Kelas IIA Permisan Nusakambangan itu sendiri. Untuk menspesifikasikan subjek dalam penelitian ini, peneliti memberikan beberapa kategori, yaitu berjenis kelamin laki-laki, beragama Islam, dan menunggu eksekusi mati lebih dari sepuluh tahun. Maka berdasarkan beberapa kategori tersebut, penulis mendapatkan tiga narapidana hukuman mati yang menjadi subjek penelitian, yaitu saudara $\mathrm{AH}, \mathrm{YM}$, dan PL dengan kasus pidana yang berbeda. Pada tahap selanjutnya, informasi dari subjek penelitian tersebut menjadi data primer, 
sedangkan data sekunder terdiri dari beberapa tulisan yang terkait, semisal jurnal ilmiah, skripsi, tesis, disertasi, majalah, dan buku.

Kedua jenis data tersebut dikumpulkan dengan teknik wawancara yang mendalam, observasi dan dokumentasi serta dianalisis dengan cara reduksi data, dimana ucapan-ucapan yang disampaikan oleh informan akan diolah dalam bahasa yang lebih sederhana dan mudah dipahami tanpa mengubah substansi yang ingin disampaikan oleh informan, sehingga dari datadata tersebut dapat diketahui kondisi religiusitas para terpidana hukuman mati. Sedangkan dalam menguji kredibilitas data, penulis menggunakan beberapa sumber data yang diperoleh melalui metode triangulasi.

Hasil dari pengumpulan data tersebut tentu saja memunculkan deskripsi baru mengenai tema yang dibahas dalam penelitian ini, dan pada tahap akhir, deskripsi tersebut dipadukan dengan berbagai data sekunder lain yang diperoleh, sehingga menjadi data yang valid dan kuat.

\section{Diskursus Teoritik Religiusitas: Makna dan Dimensi}

Menurut Glock dan Stark, sebagaimana yang dikutip oleh Ancok dan Suroso, religiusitas atau keberagamaan diwujudkan dalam berbagai sisi kehidupan manusia, tidak hanya terjadi dalam perilaku ritual (peribadatan) atau perilaku yang identik dengan keagamaan saja, tetapi juga kegiatan lain yang tidak nampak (dalam hati manusia).

Berdasarkan asumsi dasar tersebut, Glock dan Stark berpendapat bahwa religiusitas dapat dilihat dan diamati dari beberapa hal, seperti seberapa jauh pengetahuan, tingkat keyakinan akan ajaran agama, penghayatan terhadap nilai-nilai agama yang terinternalisasi dalam ketekunan pelaksanaan ajaran agama (beribadah). Pada tahap selanjutnya, beberapa keadaan tersebut dapat dirumuskan menjadi lima dimensi religiusitas; dimensi keyakinan, dimensi praktik agama, dimensi pengalaman, dimensi pengetahuan agama, dan dimensi pengamalan (Ancok dan Suroso, 2011).

Sedangkan menurut Habanakah, religiusitas sendiri memiliki beberapa dimensi, yaitu dimensi falsafah ilmiah: pembentukan akidah Muslim (akidah Islam), gejala perilaku: sesuai dengan akidahnya (syariah) dan target serta tujuannya dalam memeluk Islam (akhlak) (Habanakah, 2004).

Selaras dengan ketiga dimensi tersebut, Endang Saifuddin Anshari juga mengungkapkan bahwa dalam hal beragama, Islam dibagi menjadi tiga bagian pokok yaitu akidah (tauhid), syariah, dan akhlak. Tiga bagian ini juga senada dengan pendapat Glock dan Stark. Dimana dimensi keyakinan disejajarkan dengan akidah, dimensi praktik agama disejajarkan dengan dimensi syariah, dan dimensi pengamalan disejajarkan dengan akhlak (Ancok dan Suroso, 2011).

Maka dalam melakukan analisis pada penelitian ini, penulis lebih condong menggunakan teori religiusitas dari Habanakah. Adapun dalam beragama, akidah (kepercayaan) adalah bidang teori yang perlu dipercayai terlebih dahulu sebelum yang lainnya. Dikatakan demikian, karena akidah merupakan seruan dan penyiaran yang pertama dari Rasulullah SAW untuk dipercayai oleh manusia (Syaltut, 1984).

Secara etimologis, akidah sendiri berasal dari kata 'aqada, ya'qidu. 'aqdan atau aqîdatan, yang berarti simpul, ikatan, perjanjian yang kokoh. Relevansi antara arti kata 'aqdan dan 'aqîdatan adalah keyakinan itu tersimpul dengan kokoh di dalam hati, bersifat mengikat, dan mengandung perjanjian (Ilyas, 2016). Dari perspektif etimologis ini dapat disimpulkan bahwa makna dari keyakinan yang kokoh dalam hati adalah akidah merupakan keyakinan yang tertanam dalam lubuk hati manusia. Akidah seorang Muslim juga memiliki dasar falsafah ilmiah, atau landasan pokok yang logis dan jalan lurus yang harus ditaati oleh seorang Muslim dengan segala konsekuensinya, karena akidah itu sendiri bersifat mengikat dan mengandung perjanjian.

Dalam Islam, pembahasan tentang akidah terfokus pada enam pokok penting yaitu akidah kepada Allah, akidah kepada malaikatmalaikatNya, akidah terhadap kitab-kitabNya, akidah terhadap rasul-rasulNya, akidah terhadap hari kiamat, serta akidah terhadap takdir Allah yang baik dan buruk. Dimana pokok-pokok akidah tersebut sering disebut sebagai rukun iman.

Untuk dapat memahami lebih jauh tentang akidah yang tertanam pada diri manusia, maka perlu juga dipahami tentang beberapa aspek yang terdapat dalam diri manusia itu sendiri, yaitu: (1) fiprah manusia dalam mengakui kebenaran 
(bertuhan), indera untuk mencari kebenaran, akal untuk menguji kebenaran dan membutuhkan wahyu (Al-Qur'an) untuk menjadi pedoman menentukan mana yang benar dan tidak; (2) Keyakinan tidak boleh bercampur sedikitpun dengan keraguan, dalam arti, seseorang harus menolak segala sesuatu yang bertentangan dengan kebenaran itu; (3) Akidah harus mendatangkan ketentraman jiwa. Artinya, seseorang yang menjalankan keyakinannya harus tanpa paksaan atau berpura-pura sehingga dalam melaksanakan keyakinan tersebut akan mendatangkan ketenangan dan ketentraman jiwa (Ilyas, 2016).

Dimensi yang kedua adalah syari'ah yang merupakan kumpulan norma hukum. Kata tasyrî́ sendiri merupakan bentuk masdar yang bermakna menciptakan dan menetapkan syariah. Dalam istilah para ulama fikih, syariah bermakna “... menetapkan norma-norma hukum untuk menata kehidupan manusia, baik dalam hubungannya dengan Tuhan, maupun dengan umat manusia lainnya" (Suprapto, 2010).

Seiring dengan makna kata syariah itu, Mahmud Syaltut menyebutkan bahwa syariah merupakan susunan, peraturan dan ketentuan yang disyariatkan Tuhan agar manusia dapat melakukannya dalam rangka mengatur hubungan dengan Allah dan hubungan dengan sesama manusia. Dalam Islam, hubungan dengan Allah disebut dengan ibadah yang di dalamnya terdapat ketentuan-ketentuan atau hukum yang berkaitan dengan penghambaan seorang mukallaf. Sedangkan hubungan antar sesama manusia disebut sebagai mu'âmalah yang mencakup ketentuan-ketentuan hukum mengenai kegiatan praktis manusia dalam hal perekonomian, urusan keluarga, harta, dan lain sebagainya (Syaltut, 1984).

Secara tidak langsung, aspek kedua ini sekaligus sebagai implementasi aspek yang pertama (akidah). Karena sebuah keyakinan harus dibuktikan dengan ritual peribadatan atau dalam konteks Islam, aspek peribadatan tersebut adalah pelaksanaan salat, zakat, puasa, dan haji bagi yang memiliki kemampuan. Dimana maksud dari keempat peribadatan tersebut ditujukan untuk memurnikan hati dan memperkuat keimanan. Tidak mengherankan apabila keempat peribadatan tersebut ditambah dengan pengakuan atas Keesaan Allah dan kerasulan Nabi
Muhammad SAW disebut tiang utama untuk tegaknya agama Islam (Syaltut, 1984).

Dimensi ketiga adalah akhlak yang secara etimologis merupakan bentuk jamak dari khulq yang berarti budi pekerti, perangai, tingkah laku atau tabiat. Secara istilah, akhlak menurut Ibrahim Anis sebagaimana yang dikuti oleh Ilyas, akhlak merupakan "... sifat yang tertanam dalam jiwa, yang dengannya lahirlah macam-macam perbuatan, baik atau buruk tanpa membutuhkan pemikiran dan pertimbangan" (Ilyas, 2016).

Dari definisi ini, jiwa adalah bagian penting dalam diri manusia, di dalamnya tertanam berbagai sifat yang melahirkan akhlak, atau dapat dikatakan bahwa akhlak menjadi sisi yang membatasi dan mengarahkan tujuan yang ingin dicapai oleh seorang Muslim dalam memeluk agama Islam.

Tiga dimensi religius tersebut saling mengikat satu dengan yang lain. Secara normatif, akidah sendiri telah tertanam sejak zaman azali (Ancok \& Suroso, 2011). Seseorang yang memiliki akidah yang kuat, pasti akan melaksanakan ibadah dengan tertib, memiliki akhlak yang mulia dan ber-mu'âmalât dengan baik. Dalam Islam, keimanan merupakan pondasi yang menjadi syarat diterimanya ibadah manusia. Begitu pula sebaliknya, tidak cukup hanya beriman, seorang Muslim juga dituntut untuk melaksanakan perintah-perintah yang membuktikan dirinya telah beriman (Ilyas, 2016).

Sampai di sini, kita dapat melihat pertautan antara tiga dimensi tersebut yang tidak dapat dipisahkan satu dengan yang lain. Sehingga dalam masyarakat Muslim, tiga dimensi pokok tersebut harus ada, serta dapat diamati dalam kehidupan sosial.

\section{Faktor-Faktor yang Mempengaruhi Perkembangan Religiusitas}

Dalam menjalankan perintah keagamaan, tentunya akan ada lika-liku yang dihadapi dalam proses menuju ke arah yang lebih baik. Hal itu disebabkan karena kondisi iman manusia yang kadang naik dan juga turun. Sebagaimana yang diterangkan dalam Q.S. Al-Fat\% ayat 4, "Supaya keimanan mereka bertambah disamping keimanan mereka (yang telah ada)."

Sampai di sini, dapat diketahui beberapa hal yang dapat mempengaruhi kondisi keimanan. Seperti yang dijelaskan Thouless dan dikutip oleh 
Azizah, ada empat faktor yang dapat mempengaruhi perkembangan religiusitas seseorang: (1) Faktor sosial yang meliputi semua pengaruh sosial seperti pendidikan dan pengajaran dari orang tua, tradisi-tradisi dan tekanan sosial. (2) Faktor alami yang meliputi pengalaman-pengalaman baik yang bersifat alami, seperti pengalaman konflik moral maupun pengalaman emosional. (3) Faktor kebutuhan untuk memperoleh harga diri dan kebutuhan yang timbul karena adanya kematian, dan (4) Faktor intelektual yang menyangkut proses pemikiran verbal terutama dalam pembentukanpembentukan keyakian agama (Aziziah, 2005). Berkaitan dengan hal tersebut, Carl Gustav Jung juga mempunyai pendapat yang tidak jauh berbeda (Jung, 1966).

Dari dua pendapat tersebut, kita bisa melihat bahwa agama dalam tahap ritual dipengaruhi oleh realitas suci, sehingga secara psikologi masyarakat beragama menjadi "takut" realitas suci itu murka, sehingga secara tidak sadar, realitas suci itu dipuja dalam ritual-ritual keagamaan mereka. Pada tahap inilah psikologi bersinggungan dengan agama. Orang melakukan ritual tertentu disebabkan oleh banyak faktor dan salah satunya itu adalah faktor psikis. Michael Argyle menyatakan,

“... bahkan penjelasan akan diberikan untuk mengetahui mengapa individu memegang keyakinannya. Sebagai contoh, ada beberapa percobaan pada produksi kesadaran dari negara yang tidak biasa dipengaruhi oleh obat-obatan dan demikian pula dengan perilaku moral dan keyakinan dapat dipelajari pula. Dan ada banyak penelitian yang menjelaskan bagaimana model dan fungsi kepribadian manusia. Jadi semua bidang kegiatan manusia dan pengalaman telah dianggap sebagai lingkup khusus agama dan itu juga telah dipelajari oleh psikolog ..." (Argyle, 2000).

Tiga tokoh psikologi tersebut mempunyai pendapat yang tidak jauh berbeda. Mereka samasama meyakini bahwa perilaku keagamaan disebabkan oleh realitas lain yang berada di luar atau dalam diri seseorang. Selain itu, ritual-ritual keagamaan juga memberikan warna tertentu bagi kondisi psikis individu (Richards, t.th). Pada tahap ini, psikologi dan agama dapat dipertemukan atau bahkan agama dapat dijadikan objek kajian psikologi untuk melihat bagaimana relasi antara dua konsep tersebut.

Beberapa faktor yang mempengaruhi kondisi psikologis-religius tersebut didekonstruksi menjadi dua faktor utama, yaitu faktor internal dan eksternal. Faktor internal terdiri dari motivasimotivasi yang timbul dari dalam diri sendiri, seperti pengalaman-pengalaman baik dan buruk di masa lalu, faktor ketakuan akan kematian dan faktor pemikiran-pemikiran keagamaan tertentu.

Sedangkan yang dimaksud dengan faktor eksternal adalah segenap motivasi yang timbul dari luar diri, baik dari keluarga, teman atau kondisi sosial tertentu. Dua faktor ini akan menjadi sudut pandang utama dalam menganalisis motivasi utama para narapidana vonis hukuman mati dalam perkembangan religiusitasnya.

\section{Pembahasan \\ Lembaga Pemasyarakatan Nusakambangan}

Secara administratif-geografis, Pulau Nusakambangan terletak di Kelurahan Tambakreja, Kecamatan Cilacap Selatan, Kabupaten Cilacap, Jawa Tengah. Pulau Nusakambangan lebih dikenal sebagai pulau penjara, karena di tempat tersebut, terdapat beberapa Lapas yang mempunyai tingkat keamanan yang tertinggi di Indonesia.

Selain itu, Pulau Nusakambangan juga menjadi tempat transit bagi narapidana yang akan dieksekusi mati. Sebelum ditetapkan sebagai pulau penjara, Pulau Nusakambangan dahulunya berstatus sebagai "monumen alam" berdasarkan Staatsblad Van Nederlanschindie tahun 1923 No. 382 yang menyebutkan tentang batas lahan pulau Nusakambangan sebagai monumen alam. Namun peraturan tersebut hanya bertahan sampai tahun 1922, karena setelah itu, pemerintah Hindia Belanda kembali mengeluarkan peraturan baru terkait status Pulau Nusakambangan yang berubah menjadi tempat narapidana.

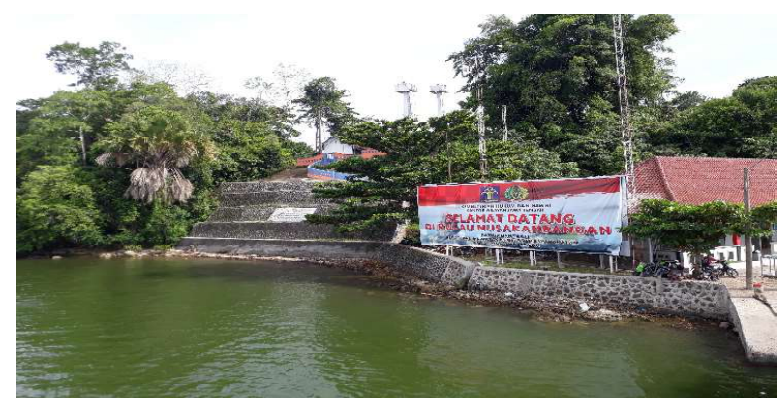

Gambar 1 Pintu Gerbang Nusakambangan 
Berdasarkan keputusan Gubernur Jenderal Hindia Belanda tanggal 24 Juli 1922 No. 25 yang dimuat dalam Berita Negara Hindia Belanda tahun 1928 No. 381 tentang wujud penjara Banyumas. Petunjuk yang berlaku untuk seluruh Pulau Nusakambangan sebagai tempat untuk menghukum para narapidana. Keputusan ini kemudian diperkuat dengan dikeluarkannya Staatsblad Nederlansch-Indie (Lembaran Negara Hindia Belanda) tahun 1937 No. 369 yang menyebutkan bahwa Pulau Nusakambangan merupakan daerah tertutup untuk penyelidikan, pertambangan, dan kepentingan umum.

Melalui SK Gubernur Hindia Belanda Nomor 32 Tahun 1937 tersebut, kewenangan atas Pulau Nusakambangan diberikan sepenuhnya kepada Departemen Van Justitie untuk dijadikan tempat pelaksanaan pidana penjara. Namun setelah masa pendudukan Hindia Belanda berakhir, kewenangan atas pengelolaan pulau Nusakambangan berada di bawah Menteri Kehakiman RI atau yang saat ini disebut dengan Kementrian Hukum dan HAM RI.

Seiring berjalannya waktu, status pulau Nusakambangan sebagai wilayah tertutup bagi penelitian dan eksplorasi pertambangan dicabut melalui Keppres Nomor 38 Tahun 1974, dan sejak itu pula, kegiatan di Pulau Nusakambangan bertambah dengan adanya pertambangan, perkebunan, pertanian, dan perikanan. Sehubungan dengan hal tersebut, pada masa pemerintahan Belanda di pulau Nusakambangan terdapat Sembilan Lapas yang beroperasi di antaranya:

1. Lapas Permisan dibangun pada tahun 1908 dengan luas $11.467,52 \mathrm{~m}^{2}$ dengan status saat ini adalah beroperasi.

2. Lapas Karanganyar dibangun pada tahun 1912 dengan luas 6.208,64 $\mathrm{m}^{2}$ dengan kondisi saat ini sudah tidak aktif dan sudah dihapus.

3. Lapas Nirbaya dibangun pada tahun 1912 dengan luas 13.046,25 $\mathrm{m}^{2}$ dengan kondisi saat ini sudah tidak aktif dan sudah dihapus.

4. Lapas Batu dibangun pada tahun 1924 dengan luas $9.993,50 \mathrm{~m}^{2}$ dengan kondisi saat ini beroperasi.

5. Lapas Besi dibangun pada tahun 1927 dengan luas $10.027 \mathrm{~m}^{2}$ dengan kondisi saat ini beroperasi.

6. Lapas Gliger dibangun pada tahun 1928 dengan luas $4.659,30 \mathrm{~m}^{2}$ dengan kondisi saat ini tidak aktif dan sudah dihapus.

7. Lapas Karang Tengah dibangun pada tahun 1928 dengan luas $3.200 \mathrm{~m}^{2}$ dengan kondisi saat ini sudah tidak aktif dan sudah dihapus.

8. Lapas Limus Buntu dibangun pada tahun 1935 dengan luas 4.320,75 $\mathrm{m}^{2}$ dengan kondisi saat ini sudah tidak aktif dan sudah dihapus.

9. Lapas Kembang Kuning dibangun pada tahun 1950 dengan luas $12.597 \mathrm{~m}^{2}$ dengan kondisi saat ini beroperasi.

Berdasarkan Surat Keputusan Menteri Kehakiman tanggal 26 Februari 1985 Nomor M.01.PR.07.03 tahun 1985, di antara sembilan Lapas yang ada, lima di antaranya dihapuskan dan tersisa empat Lapas yang masih beroperasi atau aktif; Lapas Batu, Lapas Besi, Lapas Kembang Kuning, dan Lapas Permisan. Namun beberapa tahun kemudian, kembali dibangun tiga Lapas baru untuk memenuhi kebutuhan, yaitu Lapas Pasir Putih, Lapas Terbuka, dan Lapas Narkotika dimana ketiga Lapas tersebut mulai beroperasi pada tahun 2007. Sehingga jumlah Lapas yang beroperasi di Nusakambangan saat itu adalah tujuh Lapas.

Seiring dengan berjalannya waktu, Direktorat Jenderal Pemasyarakatan (Ditjen PAS) Kementerian Hukum dan HAM (Kemenkumham) telah melakukan revitalisasi fungsi-fungsi lapas sebagai upaya pembinaan. Revitalisasi Lembaga Pemasyarakatan tersebut dimulai pada Agustus 2018 dengan melakukan penggolongan Lapas sesuai dengan tingkat keamanan dan resiko narapidananya.

Ada empat golongan atau tingkatan Lapas berdasarkan tingkat keamanannya, di antaranya adalah Lapas dengan tingkat keamanan minimal atau lapas minimum security, kemudian medium security, maxmimum security dan yang paling tinggi atau beresiko adalah Lapas super maximum security dan high risk.

Adapun Lapas dengan kategori minimum security dikhususkan bagi narapidana yang akan memasuki masa bebas tahanan. Sehingga di Lapas ini, narapidana diberikan kesempatan untuk melakukan aktivitas di luar Lapas dalam upaya pengembangan dan pembiasaan sebelum kembali ke masyarakat.

Sedangkan Lapas medium security diperuntukkan bagi narapidana yang dianggap telah kooperatif dan dapat bersosialisasi dengan baik antar sesama. Lapas ini difokuskan sebagai 
tempat penyaluran bakat dan pengembangan keterampilan narapidana. Sehingga narapidana yang tinggal di Lapas medium security diberikan kebebasan untuk mengikuti kegiatan ekstra yang difasilitasi oleh Lapas, seperti keterampilan membatik, otomotif, musik, keagamaan, dan lain sebagainya. Hal ini bertujuan untuk membangun kreatifitas dan sebagai usaha mengembangkan perekonomian mandiri kreatif dari narapidana itu sendiri.

Kategori ketiga adalah Lapas maximum security, dimana Lapas dengan kategori ini memiliki tingkat keamanan yang lebih tinggi dibandingkan dengan minimum dan medium security. Narapidana yang tinggal di dalamnya, dianggap beresiko dan harus dilakukan pengawasan dengan tingkat yang lebih tinggi dibandingkan dua kategori sebelumnya.

Adapun Lapas super maximum security dan high risk merupakan Lapas dengan tingkat keamanan yang sangat tinggi dan narapidana yang tinggal di dalamnya adalah narapidana yang dianggap sangat beresiko, sehingga dalam Lapas tersebut dilakukan pengawasan penuh dan ketat selama 24 jam. Penempatan narapidananya dalam penjara pun dibatasi; satu orang untuk setiap sel. Sehingga tidak ada komunikasi yang terjadi antar warga binaan satu dengan yang lainnya. Dikarenakan Lapas ini juga high risk, petugas di dalamnya pun harus mengenakan pakaian khusus tertutup beserta pelindung kepala dan wajah.

\section{Lapas Kelas IIA Permisan Nusakambangan: Sumber Daya Manusia dan Narapidana}

Untuk menunjang program pemasyarakatan berjalan baik sesuai dengan visi dan misi, Lapas Permisan sendiri memiliki sumber daya manusia sebanyak 60 orang yang terdiri dari 58 laki-laki dan 2 perempuan dengan klasifikasi sebagaimana yang tertera pada tabel nomor satu.

Beberapa SDM tersebut membina 483 narapidana sebagaimana data pada bulan Februari 2020. 44 di antaranya adalah narapidana yang mendapat hukuman seumur hidup, dan 21 orang adalah narapidana yang mendapat vonis hukuman mati dengan jenis kejahatan yang berbeda-beda.
Tabel 1. Rincian Pegawai Lapas Kelas IIA Permisan

\begin{tabular}{|c|c|c|}
\hline $\mathrm{NO}$ & SEKSI/BAGIAN & JUMLAH \\
\hline \multirow[t]{2}{*}{1} & Kepala Lembaga & 1 Orang \\
\hline & Pemasayarakatan & \\
\hline 2 & Kepala Sub Bagian Tata Usaha & 1 Orang \\
\hline \multirow[t]{2}{*}{3} & Kepala Kesatuan Pengamanan & 1 Orang \\
\hline & Lembaga Pemasyarakatan & \\
\hline \multirow[t]{2}{*}{4} & Kepala Seksi Administrasi & 1 Orang \\
\hline & Keamanan dan Tata Tertib & \\
\hline \multirow[t]{2}{*}{5} & Kepala Seksi Bimbingan & 1 Orang \\
\hline & Narapidana dan Anak Didik & \\
\hline 6 & Kepala Urusan Umum & 1 Orang \\
\hline 7 & $\begin{array}{l}\text { Kepala Urusan Kepegawaian } \\
\text { dan Keuangan }\end{array}$ & 1 Orang \\
\hline 8 & Kepala Sub Seksi Keamanan & 1 Orang \\
\hline 9 & $\begin{array}{l}\text { Kepala Sub Seksi Pelaporan } \\
\text { dan Tata tertib }\end{array}$ & 1 Orang \\
\hline 10 & Kepala Sub Seksi Sarana Kerja & 1 Orang \\
\hline \multirow[t]{3}{*}{11} & Kepala Sub Seksi Bimbingan & 1 Orang \\
\hline & Kemasyarakatan dan & \\
\hline & Perawatan & \\
\hline 12 & $\begin{array}{l}\text { Staf Urusan Kepegawaian dan } \\
\text { Keuangan }\end{array}$ & 3 Orang \\
\hline 13 & Anggota RUPAM & 34 Orang \\
\hline 14 & Staf Urusan Umum & 3 Orang \\
\hline 15 & Pengelola Barang Milik Negara & 1 Orang \\
\hline \multirow[t]{2}{*}{16} & Pengelola Hasil Kerja dan & 2 Orang \\
\hline & Bimbingan Kerja & \\
\hline \multirow[t]{3}{*}{17} & Staf Sub Seksi Bimbingan & 1 Orang \\
\hline & Kemasyarakatan dan & \\
\hline & Perawatan & \\
\hline 18 & Staf Sub Seksi Portatib & 2 Orang \\
\hline 19 & Staf Sub Seksi Keamanan & 3 Orang \\
\hline
\end{tabular}

Dari 21 orang terpidana mati, peneliti mendapatkan tiga orang yang sesuai dengan kategori narasumber yang telah dijelaskan sebelumnya. Adapun ketiga subjek penelitian tersebut berinisial AH, YM, dan PL yang merupakan terpidana mati dengan kasus atau pidana kejahatan yang berbeda-beda.

\section{Sketsa Religiusitas Narapidana Vonis Hukuman Mati}


Gambaran religiusitas dari narapidana vonis hukuman mati di Lapas Kelas IIA Permisan Nusakambangan dapat diketahui dari perilaku dalam kegiatan sehari-hari di dalam Lapas. Terdapat beberapa program yang difasilitasi oleh Lapas dalam menunjang kegiatan rohani warga binaan. Program yang dimaksud adalah pelaksanaan salat 5 waktu secara berjamaah di Masjid dan kajian pendalaman ajaran-ajaran keIslam-an.

Selain dengan program peningkatan kerohanian tersebut, terdapat bentuk ibadah lain seperti pelaksanaan salat sunnah dan beberapa program sosial yang dilakukan berdasarkan kesadaran dari masing-masing warga binaan.

\section{Dimensi Akidah (Keyakinan)}

Dari tiga informan yang diwawancarai, semuanya mengaku bahwa mereka telah benarbenar beriman dan memegang teguh keimanan tersebut. Bahkan subjek AH mengakui bahwa perbuatan masa silamnya tersebut menciderai keyakinan yang selama ini dia pegang teguh (Wawancara AH, 4 Februari 2020). Pengakuan tersebut sekaligus menggambarkan tentang kuatnya akidah yang dipegang oleh subjek $\mathrm{AH}$.

Pengakuan tersebut selaras dengan pendapat Ilyas dan Habanakah yang menyatakan bahwa akidah Islam yang benar dibentuk dengan meyakininya sepenuh hati dan bentuk keyakinan tersebut tercermin dalam perasaan menyesal telah melakukan perbuatan yang buruk yang disertai dengan keinginan untuk merubahnya (Ilyas, 2016). Subjek AH juga mengakui bahwa dia telah berpasrah diri kepada takdir Tuhan yang telah digariskan. Hal ini dalam pandangan Sabiq merupakan jalan bagi kesanggupan dan menjalani rintangan hidup (Sabiq, 1985).

Tidak jauh berbeda, subjek YM juga mengakui kesalahan masa lalu yang telah diperbuat. Bahkan dia mengakui tentang perbuatan-perbuatan jahat yang telah dia lakukan selama ini. Selain itu, subjek YM juga mengakui bahwa perbuatan jahat yang dilakukan tersebut menciderai perasaan ibunya sendiri (Wawancara YM, 5 Februari 2020).

Dalam Al-Qur'an, larangan menyekutukan Allah dan berbakti kepada orang tua kerap kali disandingkan. Sebagaimana yang terdapat dalam Al-Qur'an surat al-Nisâ' ayat 36, "Sembahlah Allah dan janganlah kamu mempersekutukanNya dengan selainNya serta berbuat baiklah kepada kedua orang tua ..." Menurut al-Qusyarî, ayat tersebut menjelaskan bahwa berbakti kepada orang tua adalah jalan pertama menuju pengenalan terhadap Allah (Al-Qusyairy, 2007).

Tidak jauh berbeda dengan dua narapidana hukuman mati di atas, subjek PL juga mempunyai keyakinan yang sangat kokoh terhadap agamanya, "Saya itu yakin, kalau yang menentukan hidup dan mati itu cuma Allah saja. Perkara saya mati di tiang eksekusi atau tidak, Allah sudah atur semua itu, buktinya saya sudah eksekusi tahap tiga, tapi masih hidup sampai sekarang. Semua itu tidak akan terjadi kalau bukan atas izin Allah ..." (Wawancara PL, 6 Februari 2020).

Dari pernyataan singkat ini dapat digambarkan betapa kuat keyakinan subjek PL terhadap ketentuan Allah berupa kematian. Keyakinan semacam ini juga dijelaskan dalam AlQur'an surat Al-A'râf ayat 34, "Dan setiap umat mempunyai ajal (batas waktu). Apabila ajalnya tiba, mereka tidak dapat meminta penundaan atau percepatan sesaat pun". Pengalaman tiga kali gagal eksekusi tentu saja semakin menambah kuat keyakinan subjek PL terhadap ketentuan Allah dalam hal kematian, dan seringkali pengalaman (sebab eksternal) membentuk pola keyakinan dalam diri manusia (Jung, 1966).

Jika diamati secara mendalam, tiga subjek di atas memiliki kesamaan perinsip, yaitu kuatnya keyakinan akan segenap ketentuan Allah dan sikap berpasrah diri (tawakkal) atas segenap pengalaman hidup yang mereka jalani, terlebih saat di penjara. Tiga subjek seolah-olah siap dengan segenap resiko perbuatan "dosa" masa lalu yang telah diperbuatnya.

Diakui atau tidak, keyakinan yang mengkristal dan sikap berpasrah diri itu memang timbul dari pengalaman-pengalaman masa lalu yang telah dilalui dan dielaborasi dengan pengalaman spritualitas selama berada di penjara.

\section{Dimensi Syariah (Peribadatan)}

Di dalam Lapas sendiri memang kerap kali digelar berbagai macam ritual peribadatan, mulai dari salat lima waktu sampai pengajian keagamaan. Subjek AH tetap mengikuti beberapa kegiatan tersebut. Selain itu, dia juga menceritakan tentang dirinya yang tetap melaksanakan zikir, salat sunah, dan puasa Senin-Kamis (Wawancara $\mathrm{AH}, 4$ Februari 2020). Selain itu, subjek AH juga tetap memperkuat ikatan persaudaraan antar 
sesama penghuni Lapas maupun dengan petugas Lapas.

Pada awalnya, subjek AH ditempatkan di Lapas dengan super maximum security, namun setelah dilihat perkembangan dari hari ke hari dan bersedia untuk menandatangani ikrar kesetiaan terhadap NKRI, maka dia dipindahkan ke Lapas dengan medium security. Di Lapas dengan super maximum security, para narapidana memang "kewalahan" untuk melakukan ibadah sosial (habl min al-nâs), selain karena dibatasi, juga demi menghindarkan dari keributan-keributan yang tidak dinginkan.

Namun di Lapas dengan medium security, para narapidana diberikan keleluasan untuk melakukan interaksi sosial, sehingga antar narapidana dapat saling menguatkan dan memotivasi antar satu narapidana dengan narapidana yang lain.

Begitu pula dengan subjek YM, dia juga tetap mengikuti setiap kegiatan di masjid. Hal tersebut dilakukan atas dasar kesadaran dan keinginannya untuk berubah menjadi pribadi yang lebih baik dengan meninggalkan keburukan-keburukan yang pernah dilakukan (Wawancara YM, 5 Februari 2020).

Kesadaran akan kesalahan masa lalu yang telah diperbuat serta keinginan untuk kembali menata hidup yang lebih baik menjadikan subjek YM tidak ingin kehilangan momentum untuk berbuat baik kepada semua orang di Lapas tempat tinggalnya. Selain itu, subjek YM juga menyadari bahwa umurnya sudah semakin senja, sehingga harus dimaksimalkan untuk beribadah, kecuali jika sedang sakit atau tidak kuat untuk berdiri melaksanakan salat.

Pernyataan subjek YM tersebut juga diperkuat dengan perilaku subjek yang bergegas bangun dari tempat duduk saat wawancara berlangsung ketika azan berkumandang, dan kemudian meminta maaf seraya izin untuk menunaikan salat zuhur berjamaah. Perilaku yang muncul pada subjek YM tersebut menunjukkan sebuah panggilan dari dalam dirinya untuk melaksanakan salat dengan tepat waktu dan berjamaah (kolektif). Sikap spontanitas tersebut tidak akan muncul jika perilaku tersebut tidak biasa dilakukan, karena perilaku spontan, refleksif atau respon akan langsung timbul saat menerima stimulus (Walgito, 2010).

Tidak jauh berbeda dengan dua subjek sebelumnya, dimensi peribadatan pada subjek PL juga nampak pada keseharaiannya di Lapas. Dalam kesehariannya, subjek PL bertindak sebagai takmir Masjid Lapas Permisan. Hal tersebut dilakukan dengan tujuan agar lebih memudahkan akses menuju Masjid (Wawancara PL, 6 Februari 2020). Sedangkan dalam hal muamalah, subjek PL juga merasakan rasa persaudaraan yang cukup tinggi di Lapas tempat tinggalnya (Wawancara PL, 6 Februari 2020).

Pengakuan tiga subjek di atas memberikan gambaran tentang kehidupan sehari-hari para narapidana hukuman mati di Lapas Permisan, Nusakambangan. Selain mendapatkan fasilitas tempat beribadah (masjid) dan berbagai macam program keagamaan, keinginan untuk berubah menjadi pribadi yang lebih baik juga timbul dari dalam dirinya sendiri (self). Menurut Carl Gustav Jung, motivasi yang muncul dari dalam diri sendiri (internal motivation) akan mengakibatkan perilaku yang terus menerus, karena ego selalu menciptakan kesadaran (conscious) yang tidak mempunyai batasan (Jung, 1966).

Selain itu, pengakuan tiga narapidana tersebut juga memberikan gambaran tentang keyakinan dan peribadatan bagaikan dua mata uang yang tidak dapat dipisahkan. Seperti yang dikatakan Syaltut, akidah itu adalah dasar atau pokok yang di atasnya dibangun syariat. Maka syariat itu adalah jejak langkah yang harus mengikuti akidah. Oleh karena itu, tidak akan ada syariat dalam Islam tanpa akidah, dan syariat tidak akan bisa tumbuh dan berkembang tanpa akidah.

\section{Dimensi Akhlak}

Akhlak berkaitan erat dengan kelakuan seorang individu dengan individu yang lain. Akhlak Islami sendiri muncul dari akal pikiran dan segenap potensi yang dimiliki oleh manusia, yang disempurnakan oleh petunjuk wahyu. Bukti bahwa akal dan potensi rohaniah yang dimiliki manusia dapat mengetahui sebagian baik dan buruk dapat kita lihat dalam pemikiran kaum Mu'tazilah.

Dalam pandangan aliran teologi ini, seseorang telah dapat menyatakan mencuri itu adalah perbuatan yang buruk, sedang berbuat baik kepada orang tua adalah sikap yang baik (Nata, 2012). Untuk dapat menuju kesempurnaan akhlak, ada beberapa tahapan yang harus dilalui: 
ikhtiar untuk memperdalam pengetahuan keislaman, adanya rasa syukur dan perasaanperasaan khusus dalam menjalankan keyakinan sebagai Muslim, dan yang terakhir adalah kebahagiaan dalam menggapai ridha Tuhan pada setiap perkara kehidupan.

Dalam kasus subjek AH, sikap dan kelakuan yang baik dapat kita lihat dalam kehidupan sehariharinya di dalam Lapas. Cara bergaul yang moralis dan nada bicara yang sopan, telah cukup menandakan bahwa dia merupakan orang yang mempunyai akhlak baik. Untuk sampai kepada tahapan ini, subjek AH telah banyak mendapatkan asupan pengetahuan melalui majlis taklim yang diselengggarakan dalam Lapas.

Selain menjadi program wajib bagi para narapidana, menghadiri majlis taklim dianggap menjadi kegiatan yang penting untuk dilakukan karena akan menimbulkan perasaan ingin tahu yang mendalam dan merekatkan ukhuwah antar penghuni Lapas.

Pada tahap selanjutnya, pemahaman yang benar tentang agama Islam mengantarkan kepada bertambahnya ketaatan kepada Tuhan serta menghadirkan rasa tenang dalam hati. Rasa tenang akan mengantarkan individu untuk berpikir panjang dan jernih dalam segenap permasalahan hidupnya. Tidak hanya itu, rasa tenang juga akan memadamkan sifat emosional yang mengarah kepada kehancuran dan kerusakan.

Hal tersebut juga diterangkan oleh Ancok dan Suroso, adanya perasaan-perasaan khusus atau pengalaman dalam menjalankan ajaran agama Islam seperti merasa tenteram dan tenang sebab menuhankan Allah, khusyuk ketika melaksanakan salat atau berzikir, merupakan sebuah penghayatan dalam beragama dan sebagai bukti kuatnya sebuah keyakinan (Ancok \& suroso, 2011).

Pada subjek YM, selain dengan mengikuti majlis taklim dan mempelajari Al-Qur'an seperti subjek $\mathrm{AH}$, dia juga masih sering membaca bukubuku rujukan pengetahuan Islam yang dapat diakses di perpustakaan dalam Lapas. Hal tersebut dianggap sangat membantunya untuk menambah pengetahuan tentang ajaran dan nilai Islam (Wawancara YM, 5 Februari 2020).

Mengenai hal ini, Habanakah mengatakan bahwa kegiatan membaca buku dan diskusi seperti yang dilakukan oleh subjek YM di atas, merupakan salah satu proses pengolahan informasi atau pengetahuan melalui akal dengan bertukar pendapat dan saling memberi masukan yang dapat menghasilkan pemahaman yang baik akan suatu ilmu. Sehingga dengan ilmu yang dipelajari, dapat menjadikan AH sebagai indvidu yang memiliki akhlak baik. Perilaku tersebut juga diperlihatkan oleh subjek PL, profesinya sebagai takmir Masjid Lapas memudahkannya untuk mengakses segala jenis ritual peribadatan yang diselenggarakan oleh pihak Lapas.

Selain penuturan langsung dari para terpidana hukuman mati, kondisi sosial di dalam Lapas Permisan yang sangat kondusif juga telah membuktikan adanya jalinan yang baik antara sesama warga binaan maupun petugas Lapas. Hal ini dikarenakan Lapas ini merupakan Lapas kelas medium security yang diperuntukkan bagi narapidana yang telah kooperatif dan dapat melakukan sosialisasi dengan baik. Karena lapas medium security memang difokuskan sebagai tempat untuk mengasah keterampilan para warga binaan (Wawancara Sumaryono, 7 Februari 2020).

Lagi pula, tujuan diadakan revitalisasi adalah untuk memaksimalkan fungsi pembinaan dalam Lapas itu sendiri. Maka salah satu program yang diadakan adalah dengan melakukan kerjasama untuk mengadakan program pembinaan kerohanian dengan Kementerian Agama RI dan salah satu Pondok Pesantren di Cilacap.

Program kerjasama yang dimaksud adalah kajian kerohanian atau majlis taklim yang rutin diadakan pada jadwal yang telah disepakati. Program tersebut menjadi salah satu pilihan bagi subjek penelitian untuk menambah pengetahuan keislaman mereka. Oleh karena adanya pengetahuan yang baik, dan berbagai bentukbentuk usaha untuk mengetahui pokok-pokok ajaran Islam, merupakan bentuk usaha terhadap penyucian jiwa (tazkiyah al-nafs) yang pada akhirnya menambah semangat untuk menjalani pokok-pokok ajaran Islam itu sendiri dan menerapkan sifat atau perilaku yang baik dalam kehidupan sosial.

\section{Faktor-Faktor yang Mempengaruhi Perkembangan Religiusitas Narapidana Vonis Hukuman Mati}

Secara psikologis, narapidana vonis hukuman mati dan narapidana hukuman seumur hidup mengalami perbedaan, karena harapan untuk 
hidup normal, berkumpul bersama keluarga, dan lain-lain masih terbuka lebar untuk narapidana hukuman semumur hidup. Sedangkan bagi narapidana vonis hukuman mati, harapan untuk itu sangat kecil. Apalagi, narapidana vonis hukuman mati yang penulis wawancarai belum mendapat kejelasan tentang waktu eksekusi mereka, tentu tekanan batin akan semakain terpuruk.

Maka untuk mengatasi gejolak psikologis tersebut, para narapidana vonis hukuman mati terus menerus mencari tujuan hidup serta motivasi untuk tetap dapat menjalani kehidupan dengan baik dan berlapang dada dalam menjalani hukuman. Bagi mereka, kehidupan yang religius menjadi salah satu jalan dalam menenangkan hati dalam menjalani sisa-sisa kehidupan mereka.

Jika melihat perkembangan religiusitas para narapidana vonis hukuman mati di atas, maka kita akan mendapatkan dua faktor penting yang membentuk sikap religius tersebut, yaitu faktor internal dan eksternal. Faktor internal yang dimaksud adalah dorongan atau motivasi yang timbul dari dalam diri, sedangkan faktor eksternal adalah dorongan atau motivasi yang muncul dari luar dirinya.

\section{Faktor Internal}

Dorongan mendalam dari dalam diri terwujud dalam bentuk perasaan menyesali perbuatan yang pernah dilakukan di masa lalu. Perasaan bersalah kepada keluarga korban bom yang telah diledakkan di Kedutaan Australia di Jakarta Selatan pada tahun 2004 silam, menjadi faktor penting pembentukan sikap religius subjek AH. Dia menyadari banyak korban yang jatuh akibat perbuatannya tersebut, bahkan banyak di antaranya adalah Muslim yang tak bersalah. Begitu pula dengan subjek YM dan PL, rasa menyesal terhadap perilaku masa lalu yang "arogan" menjadi motivasi penting dalam perkembangan religiusitasnya. Bahkan ketiga subjek tersebut merasa enggan untuk kembali mengingat perilaku-perilaku masa lalunya tersebut karena dianggap kurang pantas jika dilakukan oleh seorang Muslim.

Faktor internal selanjutnya yang menjadi motivasi penting dalam perkembangan religiusitas mereka adalah ketakutan terhadap kematian. Jika ditelusuri secara mendalam, setiap manusia pasti memiliki rasa takut terhadap kematian dan ada anggapan bahwa orang yang mati seperti mengalami sebuah penderitaan yang tak terbebankan.

Dengan kematian, kehidupan dunia seseorang menjadi terputus dan akan ada duka mendalam sebagaimana yang dinyatakan oleh Siti Aminah, orang yang mempunyai asumsi bahwa jiwanya akan hancur ketika kematian telah tiba, maka akan menimbulkan stres yang berkepanjangan (Aminah, 1997). Oleh karena itu, tidak mengherankan jika seseorang akan mengalami stres ketika divonis hukuman mati oleh hakim seperti kasus AH, YM dan PL di atas.

Sebenarnya akal dan perasaan manusia pada umumnya enggan menjadikan kehidupan atau eksistensi mereka terbatas pada puluhan tahun saja. Walaupun manusia menyadari bahwa mereka harus mati, namun pada umumnya manusia menilai kematian merupakan kepunahan. Keengganan manusia menilai kematian sebagai kepunahan tercermin antara lain melalui penciptaan berbagai cara untuk menunjukkan eksistensinya (Herdina 2013). Misalnya, dengan memperbanyak ritual-ritual keagamaan yang akan menyelamatkannya setelah kematian, atau dengan memperbanyak ibadahibadah sosial dan lain sebagainya.

\section{Faktor Eksternal}

Pengaruh dari luar diri manusia memang kerap kali lebih dominan dibandingkan dengan motivasi yang timbul dari dalam diri manusia itu sendiri, begitu pula pada kasus tiga terpidana mati di atas. Subjek AH menyadari bahwa program Lapas yang bekerjasama dengan pihak Departemen Agama dan pondok pesantren dalam memberikan pemahaman keagamaan yang baik, serta fasilitas-fasilitas penunjang yang baik, memudahkannya dalam proses peningkatan religiusitasnya. Subjek YM juga demikian, selama 18 tahun lamanya mendekam di Lapas, religiusitas subjek YM tidak pernah berubah.

Dia jera melakukan pelanggaran-pelanggaran baru selama berada di Lapas walaupun dengan status terpidana mati. Namun setelah adanya revitalisasi lembaga pemasyarakatan di Nusakambangan pada tahun 2018, subjek YM dimasukkan ke dalam Lapas Permisan dengan tingkat medium security, yang artinya dia telah dinilai cukup kooperatif dan tidak berbahaya bagi lingkungan. Tinggal di Lapas medium security 
membuatnya bersyukur karena setidaknya dia dapat hidup dengan layak dan dapat bersosialisasi dengan baik bersama warga binaan lainnya.

Selain lingkungan, faktor eksternal lain yang paling dominan adalah motivasi dari keluarga. Subjek YM mengakui bahwa nasehat seorang ibu sangat melekat dalam dirinya. Ingatannya pada seorang ibu yang dahulunya pernah disakiti membuat subjek YM berjanji pada dirinya untuk berubah menjadi lebih baik, dengan taat dan tunduk pada agama Islam yang sedari kecil diajarkan oleh ibunya.

Subjek YM berjanji untuk tidak lagi membuat kesalahan apapun dan tdak akan mengkhianati agamanya dengan melanggar syariat Islam. Karena dia tak ingin menyakiti ibunya kembali. Seperti yang dikatakan Thouless sebagaimana yang dikutip oleh Azizah, pengajaran dan didikan dari orang tua merupakan motivasi utama dalam meningkatkan religiusitas dan menjadi seorang Muslim yang benar (Azizah, 2006).

Pada subjek PL juga demikian, faktor yang paling mempengaruhinya untuk berperilaku religius adalah istri dan anak-anaknya. Hal itu dirasakan karena selama ini dia merasa gagal menjadi seorang suami dan ayah yang baik bagi anak-anaknya, karena dia harus menjalankan hukuman akibat pelanggaran yang telah diperbuat.

Hal itu mendorong subjek PL harus berubah menjadi manusia yang lebih baik dan taat pada agama. Selain itu, faktor kebutuhan akan harga diri juga dapat diketahui dari pernyataan subjek PL yang tetap ingin tampil menjadi sosok ayah yang baik bagi anak-anaknya walaupun dengan status sebagai narapidana. Dengan menjadi pribadi religius yang tidak pernah meninggalkan kewajiban sebagai seorang Muslim, subjek PL berharap dapat menjadi pribadi yang dapat dicontoh anak-anaknya untuk tidak meninggalkan ibadah kapanpun dan bagaimanapun situasi serta kondisi yang dihadapi.

Pada tahap selanjutnya, dua faktor di atas (internal dan eksternal) menjadi motivasi utama dalam konflik moral yang dialami oleh tiga narapidana hukuman mati, sekaligus sebagai motivasi untuk memperbaiki diri dan mendekatkan diri kepada Tuhan. Hal tersebut berjalan lurus dengan pernyataan Sabiq bahwa adanya kemampuan manusia untuk menelaah hal-hal yang salah dan tercela akan mengarahkan manusia tersebut untuk mencari jalan kebenaran dan kemuliaan spiritualitas (Sabiq, 1985).

Senada dengan Sabiq, Carl Gustav Jung juga menyatakan bahwa segenap tindakan religi dipengaruhi oleh realitas yang berada dalam diri ataupun pengaruh dari luar. Faktor internal tersebut dan segenap pengalaman masa lalu tersimpan rapi dalam kompleks. Pada tahap selanjutnya, kompleks mempengaruhi segenap perilaku religius dari seorang individu (Jung, 1966). Selain itu, beberapa motivasi eksternal juga tidak dapat dipandang sebelah mata, karena faktor ini sangat dominan dalam membentuk religiusitas para narapidana hukuman mati di atas.

\section{E. Kesimpulan}

Religiusitas narapidana vonis hukuman mati di Lapas Kelas IIA Permisan Nusakambangan begitu baik. Hal ini terlihat dari keaktifan mereka dalam menjalankan tiga dimensi religiusitas (akidah, syari'ah dan akhlak) dalam kehidupan sehari-hari di dalam Lapas. Perbuatan tersebut muncul karena dorongan dua faktor utama, faktor internal (motivasi dari dalam diri) dan faktor eksternal (motivasi dari luar diri). Faktor internal yang mempengaruhi pola religiusitas para narapidana tersebut adalah penyesalan terhadap dosa masa lalu dan ketakutan terhadap kematian. Dua hal ini memotivasi mereka untuk meningkatkan religiusitas mereka secara berkesinambungan. Sedangkan faktor eksternal yang berpengaruh adalah dukungan dari lingkungan tempat mereka mendekam saat ini, mulai dari fasilitas sarana beribadah yang mendukung, teman-teman yang religius, hingga motivasi yang datang dari keluarga, baik ibu, anak atau istri. Dua faktor ini membentuk pola religiusitas baru dan berbeda dari pola religiusitas mereka sebelumnya ketika berada di luar Lapas.

\section{UCAPAN TERIMAKASIH}

Artikel ini lahir dari penelitian penulis di Nusakambangan. Oleh karena itu, penulis mengucapkan terima kasih kepada segenap pihak yang telah membantu memudahkan penelitian di tempat tersebut; Bapak Sopian, Bapak Sumaryono, Bapak Siregar, dan beberapa petugas Lapas yang telah bersedia menemani selama melakukan penelitian. Terima kasih pula penulis haturkan 
kepada segenap subjek penelitian (Saudara PL, $\mathrm{YM}, \mathrm{AH})$ yang telah meluangkan waktu untuk bercerita tentang keluarga, keadaan selama di Lapas dan lain sebagainya yang berkaitan dengan tema artikel ini. 
Al-Qusyairi, Abu Qasim. (2007). Lapâif al-Isyârât. Beirut: Dar al-Kutub al-Ilmiah.

Ancok, Djamaludin dan Fuat Nashori Suroso. (2011). Psikologi Islami. Yogyakarta: Pustaka Pelajar

Argyle, Michael. (2000). Psychology and Religion: An Introduction. London: Routledge.

Arista, Dwi. (2017). Kebermaknaan Hidup dan Religiusitas Pada Mantan Narapidana Kasus Pembunuhan (Di Kabupaten Paser). Jurnal Psikoborneo, Vol. 5, No. 3.

Azizah, Nur. (2005). Perilaku Moral dan Religius Siswa Berlatar Belakang Pendidikan Umum dan Agama. Jurnal Psikologi Universitas Gajah Mada, Vol. 33, No 2.

Eddoyono, Supriyadi W. 2015. Hukuman Mati dalam R KUHP: Jalan Tengah yang Meragukan. Jakarta Selatan: Penerbit Institute for Criminal Justice Reform.

Frankl, Victor E. (2003). Logiterapi, Terapi Psikologi Melalui Pemaknaan Eksistensi. Yogyakrata: Penerbit Kreasi Wacana.

Habanakah, Abdurrahman. (2004). Pokok-Pokok Aqidah Islam. Jakarta: Gema Insani Press.

Herdina, Mega. (2013). Konsep Komarudin Hidayat Tentang Terapi Terhadap Kematian. Jurnal Insania, vol. 1, No. 02.

Hidayah, Evi Nurul. (2018). Bimbingan Konseling Islami dalam Upaya Penyadaran Hidup Bermakna (Studi Kasus: Narapidana Vonis Hukuman Mati Lapas Kelas IIA Permisan Nusa Kambangan). Skripsi Tidak diterbitkan, Universitas Muhammadiyah Yogyakarta.

Ilyas, Yunahar. (2016). Kuliah Aqidah Islam. Yogyakarta: Lembaga Pengkajian dan Pengamalan Islam (LPPI).

Jung, C. Gustav. (1966). Psychology and Religion. New York: The Vail-Ballou Press.

Nata, Abuddin. (2012). Akhlak Tasawuf. Jakarta: RajaGrafindo Persada.

Oktavia, Leni. (2019). Pelaksanaan Pembinaan Narapidana yang Dijatuhi Pidana Hukuman
Mati (Studi Kasus Lembaga Pemsayarakatan Kelas IA Raja Basa Bandar Lampung. Skripsi Tidak diterbitkan, Universitas Lampung Bandar Lampung.

Richards, Graham. Tt. Psychology, Religion, and the Nature of the Soul: A Historical Entanglement. United Kingdom: Springer.

Sabiq, Sayid. (1985). Aqidah Islam (Ilmu Tauhid). Bandung: Diponegoro.

Aminah, Siti. (1997). Konsep Kematian Menurut Mufassir: Studi Tentang Persiapan dan Tempat Roh Setelah Pisah dengan Badan. Skripsi tidak diterbitkan, Fakultas Ushuluddin, IAIN Antasari, Banjarmasin.

Suprapto. (2010). Aqidah Islam Menurut Hasan AlBanna (Telaah Kitab Al-Aqidah). Skripsi tidak diterbitkan, UIN Sunan Kalijaga Yogyakarta.

Syaltut, Mahmud. (1984). Aqidah dan Syariah Islam. Jakarta. PT Bina Aksara.

Tasmara, Toto. (2001). Kecerdasan Ruhaniah (Transendental Intelligence). Jakarta: Gema Insani Press.

Walgito, Bimo. (2010). Pengantar Psikologi Umum. Yogyakarta. PenerbitAND 
264 Religiusitas Narapidana Vonis Hukuman Mati ... 
